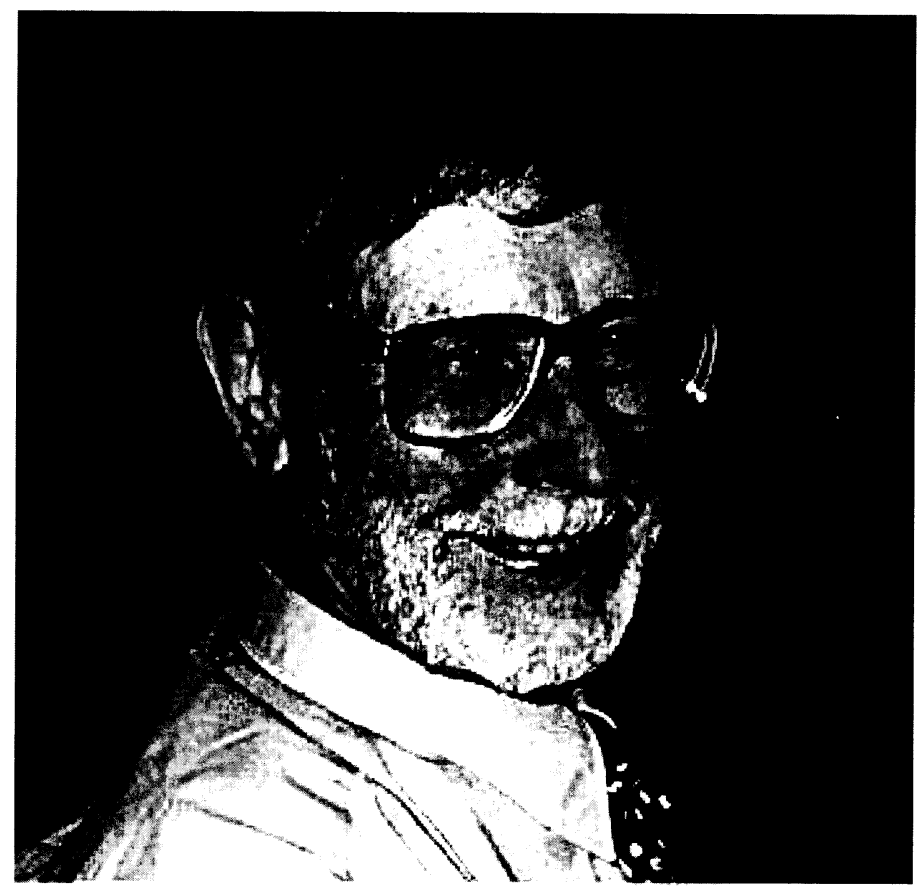

Vagn Wåhlin

16/1 1935 - 29/4 2009

(privatfoto) 


\section{Vagn Wåhlin in memoriam}

\section{Af Kim Arne Pedersen}

Det er blandt Grundtvig-forskere god tone at skabe afstand mellem N. F. S. Grundtvig og den bevægelse, der bærer hans navn. Inden for både teologisk og humanistisk forskning er billedet af Grundtvig afgørende bestemt af erkendelsesinteresser. Det gælder både, når Grundtvig-forskere med støtte i Grundtvig-udtalelser fra slutningen af 1840'erne - men i modstrid med tilsvarende fra 1860'erne proklamerer, at Grundtvig jo ikke var grundtvigianer, for derefter at gøre rede for, at Grundtvigs teologi eller samfundstænkning netop ved at blive befriet fra forbindelsen til den grundtvigianske bevægelse er aktuel og taler ind i nutiden, og når Grundtvig-forskere kontrasterer Grundtvig og den grundtvigske bevægelse med det formål at vurdere Grundtvig ud fra æstetiske kriterier.

Vagn Wåhlin gik den modsatte vej, og han gjorde det ganske bevidst, idet han anskuede Grundtvig og grundtvigianismen som led i én samlet bevægelse, dele af den samme strømning. Vagn Wåhlin betragtede den grundtvigske bevægelse - hvis skolepolitik og økonomiske politik han havde studeret indgående - som led i en samfundsmæssig virkeliggørelse af tanker, som Grundtvig havde tænkt ved sin skrivepult, og han gjorde i samtaler gentagne gange opmærksom på, hvor lang tid det havde taget ham overhovedet at "forstå" de grundtvigske skoletanker - det vil sige etablere den tolkning, der altid er faghistorikerens opgave: at se tanker og ideer i deres samfundsmæssige kontekst. Men da først forståelsen var der, rummede den i sig kimen til en række tolkninger af dansk og nordisk bevægelseshistorie, der lod sig samle i et billede, en helhedsanskuelse.

Samtidig var Grundtvig i høj grad en aktuel medspiller for Vagn Wåhlin, når det gjaldt de nutidige diskussioner om dansk national identitet. Vagn Wåhlin var ikke blot historiker af uddannelse, han var historiker på en måde, hvor historien, begivenheder og tanker, strømninger, socialhistorien og åndshistorien - og hans fortolkning af sammenhængen - så at sige var blevet hans anden natur. Han levede og åndede i den historiske analyse og det dermed forbundne engagement, både når han arbejdede med sit fag, og når han sugede til sig fra medierne.

Hvorfra kom interessen for og engagementet $i$ Grundtvig og den grundtvigske bevægelse? Det stod ikke skrevet over Vagn Wåhlins vugge, at han skulle vie størstedelen af sit arbejdsliv til studier i de danske og nordiske religiøse bevægelser. Vagn Wåhlins baggrund som han fortalte om med indføling og kærlighed - var håndværker- 
miljøerne på Nørrebro, håndværkerne, der med svendebrev og overskud oftest blev lederne i arbejderbevægelsen. I familien var der tråde til Sverige såvel som til Østprøjsen. Der var tale om et udpræget storbymiljø, medens de folkelige bevægelser, Vagn Wåhlin kom til at studere, for langt de flestes vedkommende havde deres base i den landbokultur, som voksede frem i vekselvirkning med den danske agrare modernisering fra slutningen af det 18. og ind $\mathrm{i}$ det 19. århundrede. Samtidig kunne Vagn Wåhlin - således som han demonstrerede det $\mathrm{i}$ sine store, imponerende bidrag til Grundtvig-Studier i 2003 og 2006 se sammenhænge og forbindelser. Vagn Wåhlin pointerede stedse, at barndommens håndværkerhjem var et miljø, hvor man fik en dannelse med sig, en dannelse, der var "folkelig", hvis man her bruger ordet så bredt, som det bruges af Roar Skovmand, folkelig og derfor i pagt med den modernisering af samfundet, som fandt sted fra det 19. århundredes sidste halvdel og frem gennem det 20.

Denne folkelige, socialdemokratiske dannelse udgjorde grundlaget for den lange og imponerende forskerkarriere, som Vagn Wåhlin fik, fra han i 1968 som mag. art. fra Københavns Universitet blev knyttet til Historisk Institut på Aarhus Universitet, til han pensioneredes herfra som docent i 2005. Allerede under studietiden vaktes interessen for Grundtvig, blandt andet gennem besøg i Asperup hos Grundtvigforskeren, sognepræst, dr. theol. Kaj Thaning, en interesse, der forstærkedes af Vagn Wåhlins meget omfangsrige, kildebaserede studier i forholdet mellem institutioner, ideologi og dét, som han i forlængelse af 1980'ernes universitetsmarxisme, men med en vis reservation, i de sidste år betegnede som de socio-økonomiske sammenhænge i samfundet.

Allerede i 1983 udsendte Vagn Wåhlin sammen med en række andre Århushistorikere antologien Stykkevis og delt: 5 essays om Grundtvig og grundtvigianisme, en række tekster, hvoraf ikke mindst hans elev Lars Kaaes bidrag om Grundtvigs frihedsbegreb bliver stående, et bidrag, der rummer en af de alt for få undersøgelser af Grundtvigs syn på jordpolitik og samfundsøkonomi. Vagn Wåhlin pointerede både $\mathrm{i}$ sine skriftlige arbejder og i sin undervisning ideologihistoriens og mentalitetshistoriens forbundethed med de socio-økonomiske sammenhænge. Han spændte umådelig vidt: Amerikastudier, Færøerne, de folkelige bevægelser i det 19. århundredes Danmark, både grundtvigianismen og Indre Mission, hvis skolevirksomhed han altid omtalte med respekt og beundring, trods hans eget meget anderledes udgangspunkt. Et blik på Vagn Wåhlins publikationsliste kunne gøre en yngre kollega svimmel: artikel fulgte på artikel, år efter år gennem det meste af forskerkarrieren. Han skrev om alt fra nationalromantikkens bevidste brug af folkekulturen over indremissionsk 
friskolevirksomhed til Grundtvigs økonomiske tænkning. Han spændte så vidt, at det engang imellem var lige ved at blive umuligt for ham at rumme det hele, gabe over det. Men Vagn Wåhlin insisterede på omfanget, ligesom han insisterede på sammenhængen - sammenhængen mellem det 19. århundrede og dansk selvforståelse i det 20. århundrede og sammenhængen mellem de socio-økonomiske forhold og kulturen.

Som en rød tråd i det hele går hans forskning i det 19. og 20. århundredes skolehistorie, den forskning, der både førte til den meget omfangsrige antologi med skildring af de indremissionske internatskoler og til en stor upubliceret monografi (Offentlighed og Almueskole, utrykt manuskript, 1979, 1-347) med en redegørelse for de resultatløse forsøg på at give Danmark en moderne grundskolelov, den grundskolelov, som først blev virkelighed i 1930'erne gennem socialdemokraters og radikales regeringssamarbejde og med den grundtvigianske undervisningsminister Jørgen Jørgensen som arkitekten. Vagn Wåhlins grundlæggende indsigt var her, at striden om grundskoleloven udviklede sig "fra en socio-økonomisk begrundet klassekamp til en kulturpolitisk klassekamp med grundtvigianere og nationalliberale som egentlige modstandere" (ibid. 260), en kamp, der i årtier spærrede for en lovgivning på området. I manuskriptet toner den linje i Vagn Wåhlins Grundtvig-tolkning frem, som han senere gav form i en række store artikler i Grundtvig-Studier, hans indsigt i, at en virkelig forståelse af de grundtvigske skoletanker implicerer en forståelse af Grundtvigs fornemmelse for "de reelle økonomiske og klassemassige forhold omkring arbejdet og i det vekslende behov for arbejdskraft i agrarproduktionen" (ibid. 260). Den upublicerede monografi er præget af datidens universitetsmarxistiske terminologi, men forholdet mellem basis og overbygning er ikke tænkt i en forenklet årsag-virkningssammenhæng, således som det bliver klart, når han afsluttende skriver:

Det væsentlige er ikke, finder jeg, at meget i Grundtvigs og Kolds skoletænkning og praksis ikke længere har relevans i folkeskolen, men at deres tanker stadig sætter deres spor længe efter at den socio$ø$ konomiske forudsætning herfor er radikalt ændret i vort nuværende højtindustrialiserede samfund (ibid. 264).

For Vagn Wåhlin var det derfor en grundlæggende indsigt, at "denne påvirkning kan vises den dag i dag i det danske skolesystem" (ibid. 265), en indsigt, som han udarbejdede til en egentlig tese om dansk national identitet gennem sin forskning $\mathrm{i}$ de folkelige bevægelser $\mathrm{i}$ 1980'erne, en tese, som er taget op af hans elev Uffe Østergård. Tesen går i al korthed ud på, at Grundtvigs status som nationalt ikon er betinget af det forhold, at hans tankegang i kraft af landbrugets dominans 
som vor nations bærende erhverv op til efter Anden Verdenskrig og de grundtvigske ideers vekselvirkning hermed har været bestemmende for tænkemåden i Danmark fra det 19. århundredes slutning og frem. Uffe Østergård har formuleret dette forhold således:

Grundtvigianerne kom, skønt de var i mindretal, til at dominere partiet [Venstre]. De indledte i 1870 'erne en kulturkamp med de konservative og de byliberale om magten over skole og kirke - og vandt. Denne kulturkamp om skolesystemet var i virkeligheden langt mere afgørende for etableringen af et kulturelt hegemoni og dermed det særligt "danske" ved den politiske kultur og på længere sigt en "dansk" mentalitet end den langt mere publicerede litterære kulturkamp i 1880'erne. (...) Hvis man definerer grundtvigianismen i så vid forstand, at Indre Mission, sådan som jeg skildrede det tidligere i kapitlet, hører med, kan man sige, at gårdmændenes ideologi sejrede over byborgerskabets: ikke i institutionel form, men reelt. Og ganske vist $\mathrm{i}$ en udvandet form, der får kernetropperne til at slå kors (eller Thors hammer) for sig, men alligevel. Det er nemlig grundtvigianismens præmisser, som er blevet lagt til grund for den politiske (ud)dannelse i dette land. Det er lykkedes dem at præge deres modstandere bag om deres egen selvforståelse. For mig at se er deres ideologi blevet noget før-bevidst, noget "naturligt" (i grunden burde vi vel sige kulturligt), som ikke modsiges, fordi deres program er kommet til at definere hele danskheden. Det gælder for hele den herskende elite, de borgerlige såvel som arbejderbevægelsen, uanset hvordan de er blevet rekrutteret (Uffe Østergård (1992, 2001), Europas ansigter, Nationale stater og politiske kulturer i en ny, gammel verden, København, 77-78).

Det vil være de fleste læsende danskere bekendt, at Uffe Østergård der oprindelig forholdt sig positivt til dansk national identitet - siden 1990'ernes begyndelse har benyttet tesen som afsæt for en kritik af dansk selvforståelse. Vagn Wåhlin gik en anden vej: selv om han ikke forholdt sig ukritisk til elementer i den transformation af nationsbegrebet fra en tysk til en dansk kontekst, som Grundtvig er en del af, fastholdt han værdierne i Grundtvigs pragmatisme, hans erfaringsnære evne til at tilpasse udenlandsk tankegods til en dansk virkelighed og derved etablere et sæt af ideer og forestillinger, der i snæver sammenhæng med samfundsudviklingen i Danmark fik en lang levetid. Denne tilgang til Grundtvig kommer også til udtryk i den store afhandling om Grundtvig som økonomisk tænker, han publicerede i GrundtvigStudier på overgangen til 1990'erne, og hvori han sammenfatter således:

Om man vil kalde Grundtvigs økonomi-forståelse for småborgerlig, reaktionær, liberal, konservativ, revolutionær, fysiokratisk - eller hvad, vil jeg overlade til andre at skændes om. 
Derimod vil jeg kalde den realistisk og dansk. Det første, fordi den nøgternt tog de faktiske produktionsmæssige, historiske og klassemæssige forudsætninger ind $\mathrm{i}$ en socio-økonomisk og polit-økonomisk helhedstænkning. Det andet, fordi Grundtvig af de mange tilbud på de økonomiske teoriers marked tog af dem - og transformerede dem som gav mening og kunne anvise handlingsmuligheder i Danmark uden at hævde andet, end at de måtte vise deres værdi i den danske praksis" (Vagn Wåhlin (1988-89), "Grundtvigs økonomiske tænkning”, Grundtvig-Studier 1988-89, København, 288).

Til artiklen om Grundtvigs økonomiske tænkning lægger sig en stor artikel om den slesvig-holstenske problematik i antologien Heritage and Prophecy. Grundtvig and the English-speaking World fra 1993, en udgivelse med en vedføjet fortolkende artikel af Grundtvigs "Politiske Betragtninger med Blik paa Danmark og Holsten" i Grundtvig-Studier 1994, mindre bidrag $\mathrm{i}$ form af anmeldelser og den store artikel "Folkelige og sociale bevægelser. Nyere forskningsretninger og kvalitative forståelser" - en indkredsning af et vanskeligt historisk problemkompleks - i Grundtvig-Studier 2003, en artikel, der i udvidet form blev bragt på engelsk i John Stanley Martins fine oversættelse sammesteds i 2006. Vagn Wåhlin knyttede her til ved Roar Skovmands og Pontoppidan Thyssens begreb "folkelige bevægelser" i kombination med de nyeste tendenser $\mathrm{i}$ forskningen, hvor historikerne siden 1970'erne og 1980'erne har inddraget nye emner, teorier og metoder og arbejdet på tværs af de traditionelle faggrænser. Herved blev brugen af komparation som metode central i forskningen (for eksempel i form af flere tværnationale og fællesnordiske forskningsprojekter men også inden for Danmarks grænser), ligesom det mentalitetshistoriske aspekt i kulturhistorien kom til at spille en stigende rolle. I Vagn Wåhlins artikel står det mentalitetshistoriske centralt, idet han gennem en idealtypisk skematisering skildrer forløbet inden for en folkelig bevægelse fra en "mental opvågnings- eller vækkelsesfase" (Wåhlin 2003, 29) over etableringen af et netværk og frem til institutionsdannelserne - en skildring, der ikke kan betegnes som egentlig Grundtvig-forskning, samtidig med, at Grundtvigs virke i indledningen sættes ind $\mathrm{i}$ den samfundsmæssige og bevægelseshistoriske kontekst, der var så afgørende for Vagn Wåhlin.

Vagn Wåhlins sidste år var præget af sygdom - men der var også glæder. Han var aktiv som historiker til det sidste. Karakteristisk for ham satte han sig ved flytningen til Odder - ind i den lejlighed og det hus i byen, hvor han og kunsthåndværkeren Kaisu Kirsten Salmia fik deres sidste fælles hjem - ind i, hvordan Odders matador Georg Nielsen byggede sit kombinerede handelshus og hjem på torvet, og hvordan Georg Nielsens virksomhed spillede en central rolle i Odder som handelsby midt i det dynamiske landbrugssamfund fra det 19. 
århundredes anden halvdel - en sydende "stor" lilleby med selvstændigt opland, med jernbane og indflydelsesrig andelsbevægelse, alt det, han havde forsket $i$ hele sit liv.

En anden glæde var kontakten med fagfæller. Rundt om i den danske museumsverden og på de danske universiteter sidder i dag en lang række mennesker, der - som jeg selv kom det, midtvejs i mit liv var i mesterlære hos Vagn Wåhlin og fik lært at se med hans øjne, se sammenhængene mellem samfundslivet som økonomisk-social helhed og de livsformer, den kultur, som skaber struktur i menneskers liv. Vagn Wåhlin havde en evne til at formidle interesse for historien noget han både gjorde $\mathrm{i}$ forhold til børnene Sidsel og Rane Wåhlin og i forhold til sine studerende. Vi fik alle lært at se med Vagns øjne, men vi fik lært det sådan, at vi også kunne forholde os til det, vi havde lært, bearbejde det selvstændigt og gå nye veje - trods Vagn Wåhlins insisteren på netop den sammenhæng og tolkning, han betragtede som den rette. Men netop denne insisteren var en del af hans personlighed og dermed også hans talent som lærer - et talent, der bundede i, at Vagn Wåhlin var den, han var, det insisterende menneske, der i sit nærvær og sin glødende optagethed af tingene ganske enkelt forventede, at vi andre var lige så engagerede, lige så nærværende, lige så opmærksomme på forhold, sammenhænge og lange linjer, som han selv var. Og netop ved at være den, han var - det insisterende menneske, mennesket med den stærke livstørst og livsvilje, med det brændende engagement og en higen efter viden og indsigt, efter at forstå, der aldrig nåede til hvile, aldrig blev stillet, aldrig fik nok - blev han i stand til at spænde over så store sammenhænge, som han gjorde. Dele af det efterladte utrykte forfatterskab bør udgives. Heldigvis har dansk forskning de mange artikler, hvori han har nedfældet sine iagttagelser og tolkninger, og de vil have blivende værdi i årene, der kommer. 